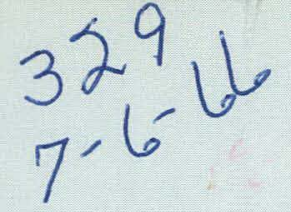

AEC RESEARCH AND DEVELOPMENT REPORT
Y-1543

Chemistry

\title{
SPARK SOURCE MASS SPECTROGRAPHIC ANALYSIS OF STEELS AND NICKEL ALLOYS (U)
}

J. C. Franklin

E. B. Griffin

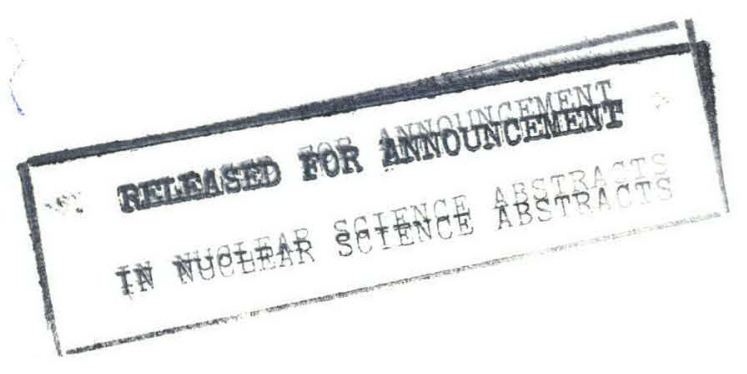

\section{UNION CARBIDE CORPORATION}

\section{NUCLEAR DIVISION OAK RIDGE Y-12 PLANT}

operated for the ATOMIC ENERGY COMMISSION under U. S. GOVERNMENT Contract W-7405 eng 26 


\section{DISCLAIMER}

This report was prepared as an account of work sponsored by an agency of the United States Government. Neither the United States Government nor any agency Thereof, nor any of their employees, makes any warranty, express or implied, or assumes any legal liability or responsibility for the accuracy, completeness, or usefulness of any information, apparatus, product, or process disclosed, or represents that its use would not infringe privately owned rights. Reference herein to any specific commercial product, process, or service by trade name, trademark, manufacturer, or otherwise does not necessarily constitute or imply its endorsement, recommendation, or favoring by the United States Government or any agency thereof. The views and opinions of authors expressed herein do not necessarily state or reflect those of the United States Government or any agency thereof. 


\section{DISCLAIMER}

Portions of this document may be illegible in electronic image products. Images are produced from the best available original document. 
Printed in USA. Price $\$ 1.00$. Available from the Clearinghouse for Federal Scientific and Technical Information, National Bureau of Standards, U.S. Department of Commerce, Springfield, Virginia

\section{LEGAL NOTICE}

This report was prepared as an account of Government sponsored work. Neither the United States, nor the Commission, nor any person acting on behalf of the Commission:

A. Makes any warranty or representation, expressed or implied, with respect to the accuracy, completeness, or usefulness of the information contained in this report, or that the use of any information, apparatus, method, or process disclosed in this report may not infringe privately owned rights; or

B. Assumes any liabilities with respect to the use of, or for damages resulting from the use of any information, apparatus, method, or process disclosed in this report.

As used in the above, "person acting on behalf of the Commission" includes any employee or contractor of the Commission, or employee of such contractor, to the extent that such employee or contractor of the Commission, or employee of such contractor prepares, disseminates, or provides access to, any information pursuant to his employment or contract with the Commission, or his employment with such contractor. 
H.C. \$1.00; MN , 50

Date Issued: July 6, 1966

Report Number_ Y-1543

Chemistry

TID -4500

\section{UNION CARBIDE CORPORATION \\ Nuclear Division}

$$
\text { Y-12 PLANT }
$$

Contract W-7405-eng-26

With the US Atomic Energy Commission

SPARK SOURCE MASS SPECTROGRAPHIC ANALYSIS

OF STEELS AND NICKEL ALLOYS (U)

J. C. Franklin

E. B. Griffin

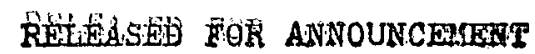

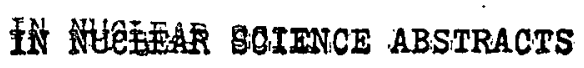

Oak Ridge, Tennessee 
Distribution:

\begin{tabular}{|c|c|c|c|}
\hline Ackerson, R. D. & (AFSC) & Hemphill, L. F. & \\
\hline Bailey, E. W. & & Hibbits, J. O. & (GE-Evendale) \\
\hline Ballenger, $H . F$. & (2) & Huber, A. P. & (ORGDP) \\
\hline Bell, B. B. & & Keller, C. A. & $(\mathrm{AEC}-\mathrm{ORO})(4)$ \\
\hline Bernander, N.K. & & Lewis, F. O. & (ORGDP) \\
\hline Blosser, E. R. & (Battelle) & Martin, W. R. & $(\mathrm{ORNL})$ \\
\hline Briscoe, O. $\dot{W}$. & & McLendon, J. D. & \\
\hline Burkhart, L. E. & . & Meeks, E. J. & $(\mathrm{AFSC})$ \\
\hline Cameron, A. E. & (ORNL) $\therefore$ & Michaelis, $R$. & (NBS) \\
\hline Center, C. E. & (ORGDP) & Mitchel, G.W. & \\
\hline Chastagner, $P$. & (SRO) & Rehn, Irwin & (Aero Jet) \\
\hline Connolly, T. F. & $(\mathrm{ORNL})$ & Schreyer, J. M. & \\
\hline Cowen, D. D. & (ORNL) & Smith, L: A. & \\
\hline Franco-Ferreira, E. A. & (ORNL) & Whitson, W. K. & \\
\hline Franklin, J.C. & (8) & Winkel, R. A. & (Paducah) \\
\hline Griffin, E. B. & (7) & Y-12 Central Files & (5) \\
\hline Harman, W. D. & & $Y-12$ Central Files & $(Y-12 R C)$ \\
\hline Harwell, W. L. & (ORGDP)(5) & & \\
\hline
\end{tabular}

In addition, this report is distributed in accordance with the category Chemistry, as given in the "USAEC Standard Distribution Lists for Unclassified Scientific and Technical Reports", TID-4500. 
Spark source mass spectrography has been utilized for the determination of boron in steels and nickel alloys. Both visual and microphotometric methods of interpreting data have been developed. The reproducibility of the microphotometer technique has been calculated from standard samples and the visual technique has been compared with conventional methods. 


\section{THIS PAGE WAS INTENTIONALLY LEFT BLANK}


CONTENTS

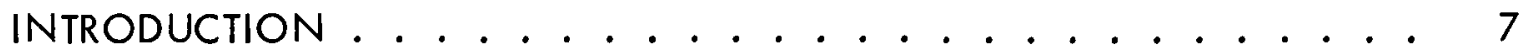

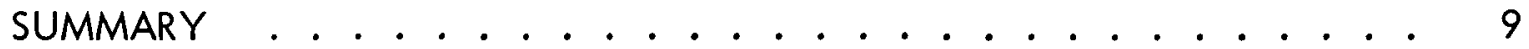

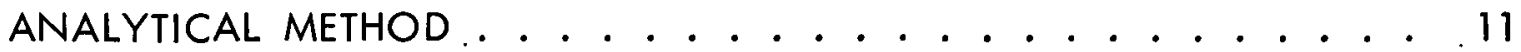

Methods of Data Interpretation . . . . . . . . . . . . . . 11

Experimental Procedure. . . . . . . . . . . . . . 12

Sample Preparation. . . . . . . . . . . . . . 12

Plate Reading . . . . . . . . . . . . . . . 13

Results and Data . . . . . . . . . . . . . 13

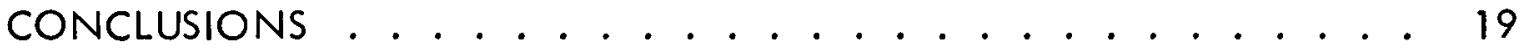


THIS PAGE

WAS INTENTIONALLY

LEFT BLANK 


\section{INTRODUCTION}

Laboratories are experiencing an increased need for determining analytically the boron content of steel and nickel alloys due to the B-10naLi-7 reaction which may lead to helium embrittlement of the alloys when exposed to high temperatures and neutron fluxes. Many alloys of this type are used in reactor assemblies.

Spark source mass spectrography has some advantages as a technique for determining the boron content in steel and nickel alloys. The sensitivity of the instrument can detect boron at the one part-per-billion level without difficulty. In addition, the samples do not have to be dissolved or chemically altered. The only preparation, after cutting, is the etching of the surface in electronic-grade acids. Another advantage of the technique is that estimations may be made on any element desired. However, the technique has one possible disadvantage - a small sample size may make results sensitive to inhomogenities in the sample. This condition can be minimized by a careful analysis of the plates and duplicate exposures of questionable samples. This inhomogenity does not seem to be as prevalent as might be expected. 


\section{THIS PAGE}

\section{WAS INTENTIONALLY \\ LEFT BLANK}


The spark source technique of analysis provides a versatile method for analyzing alloys. Detection limits are in the range of one part per billion, and the method provides good reproducibility and accuracy.

An Associated Electrical Industries spark source mass spectrograph has been utilized for the analysis. Two methods have been used to interpret the photographic plates: a microphotometer and visual estimation. Both techniques of interpretation have been applied to known standards and unknown samples. Photographic detection of positive ions is accomplished by standard IIford Q-II photographic plates. 


\section{THIS PAGE WAS INTENTIONALLY LEFT BLANK}




\section{ANALYTICAL METHOD}

\section{METHODS OF DATA INTERPRETATION}

Since the data are obtained on a photographic plate, two methods of data interpretation are immediately available. The visual-estimation method is quite simple and can be performed quickly; however, at times, precision is not very good. This method can be summarized by the following expression:

$$
P S=\frac{E_{\min }}{E_{\max }} \times \frac{\% \times}{100} \times \frac{\% I_{s t d}}{100} \times 10^{6},
$$

where:

$E_{\min }$ represents the minimum detectable exposure for a chosen internal standard isotope,

$E_{\text {max }}$ the longest exposure on the plate,

$\% \times$ the atom percent of the element chosen as the standard,

$\left.\%\right|_{\text {std }}$ the isotopic abundance of the internal standard isotope, and

PS the plate sensitivity in puin alomic.

Then:

$$
C_{i}=P S \times \frac{E_{\text {max }}}{E_{\text {det }}} \times \frac{100}{\% I_{i}},
$$

where:

$C_{i}$ represents the concentration of the impurity element in ppm atomic, $E_{\text {det }}$ the minimum exposure at which the impurity can be detected, and

$\% I_{i}$ the iostopic abundance of the impurity isotope.

This method lacks reproducibility for several reasons, and values are somewhat dependent on the personnel interpreting the data. Experienced personnel obtain very good results with this technique. 
The second method of data interpretation is somewhat more complex but provides better precision and perhaps better accuracy. This method requires a microphotometric measurement of the light transmission and subsequent conversion of this percent transmission to light intensity by an analog computer. The relative intensity is then integrated, if needed. The concentration of an impurity in a sample is then:

$$
C_{i}=\frac{E_{s}}{E_{i}} \times \frac{X}{100} \times \frac{I_{s}}{I_{i}} \times \frac{s}{S_{i}} \times \frac{A_{i}}{A_{s}} \times 10^{6},
$$

where:

$E_{s}$ represents the relative intensity of the standard line,

$E_{i}$ the relative intensity of the impurity line,

$X$ the atomic percent concentration of the standard,

Is the isotopic abundance of the standard isotope,

$I_{i}$ the isotopic abundance of the impurity isotope.,

$S_{s}$ the relative sensitivity of the standard,

$S_{i}$ the relative sensitivity of the impurity ion,

$A_{s}$ the relative area of the standard line, and

$A_{i}$ the relative area of the impurity line.

In actual practice, if the area terms are necessary, the area of the intensity curve is integrated and the $E_{s} / E_{i} \times A_{i} / A_{s}$ factors become one as an integrated relative intensity.

Precision for this method is significantly better than for the visual method of interpretation; ie, visual estimation is usually $\pm 50-100 \%$ while the microphotometer range is \pm 3 to $40 \%$.

\section{EXPERIMENTAL PROCEDURE}

Sample Preparation

The samples, either metal wires, rods, or plates, were machined or cut into rods $1 / 16$ to $1 / 8$ inch in diameter by $1 / 2$ to $3 / 4$ inch in length. 
The samples were degreased in methyl chloroform followed by two rinses in Mallinkrodt Transist AR acetone. Between acetone washes the samples were rinsed in running deionized water. After the samples were degreased, they were etched three times ( $11 / 2$ minutes) in aqua regia made from Transist AR hydrochloric and nitric acids. Between etches and after the last etch, the samples were rinsed in running deionized water. Next, the samples were loaded wet into the source of the mass spectrometer and evacuated to approximately $5 \times 10^{-7}$ torr. After cleaning was initiated, the samples were handled with tantalum forceps in Teflon beakers to minimize contamination.

Each sample was presparked to about the equivalent of a $1 \times 10^{-8}$ coulomb exposure to remove surface contamination. An IIford $Q$-II plate was then exposed in a series of graded exposures so that the shortest exposure was approximately $1 \times 10^{-13}$ coulomb and the longest about $1 \times 10^{-8}$ coulomb. This exposure schedule was found to be sufficient to provide detection limits in the 0.1 to $0.4 \mathrm{ppm}$ atomic $(0.02$ to 0.08 ppm weight) range. National Bureau of Standards steels were alternated every second or third run with the samples.

The Q-II plates were developed at $20^{\circ} \mathrm{C}$, three minutes in Kodak D-19, short stopped in dilute acetic acid, fixed in Kodak Rapid Fixer, washed for ten minutes in water, and then rinsed again in distilled water. Nitrogen burst agitation is employed on all tanks. The plates were dried for ten minutes in circulating air at $38^{\circ} \mathrm{C}$.

$\underline{\text { Plate Reading }}$

Plates are read by visual estimation on the modified microfilm reader shown in Figure 1. If microphotometric determination is desired, the plates are scanned on the Jarrell Ash 24-310 microphotometer. Transmission data are converted to intensity by a 23-515 Jarrell Ash H and D analog computer which has a previously determined plate calibration curve installed in the instrument. The output of the intensity recorder is integrated on an Infotronics Model CRS-1 integrator and amplifier when necessary. The system is schematically outlined in Figure 2.

\section{Results and Data}

Some 200 samples of steels and alloys have been analyzed for their boron content and for some other elements. This number of samples has provided adequate opportunity for cross checks with other analytical methods and the analysis of standard samples.

These samples represented many material types and concentration ranges. Table 1 presents the boron level as analytically determined for each material type.

Most of the data have been obtained by visual estimation; however, cross-check information has been accumulated when possible. In Table 2, spark-source mass 


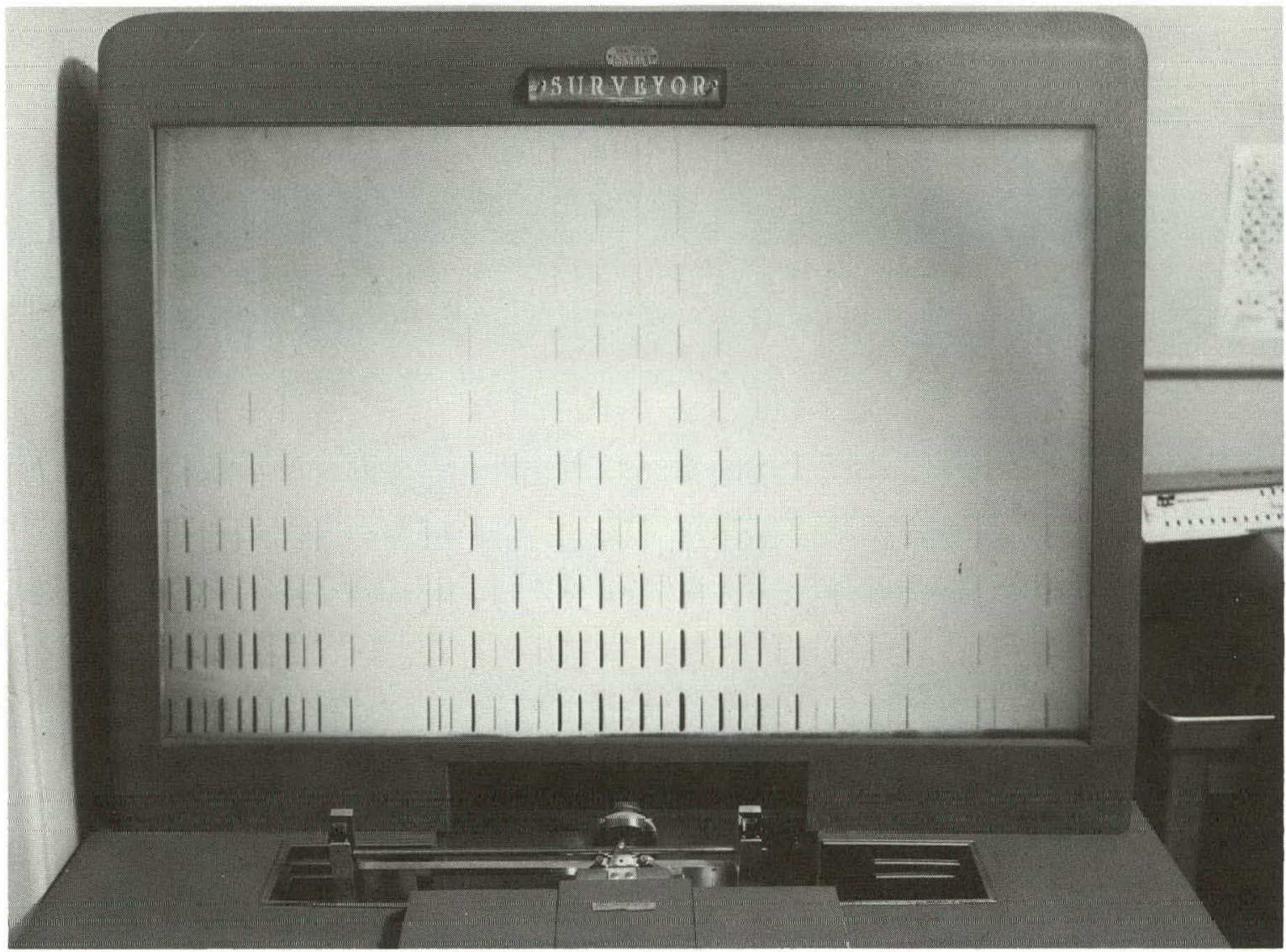

$116822(U)$

Figure 1. A MODIFIED MICROFILM READER USED TO READ PLATES BY VISUAL ESTIMATION.

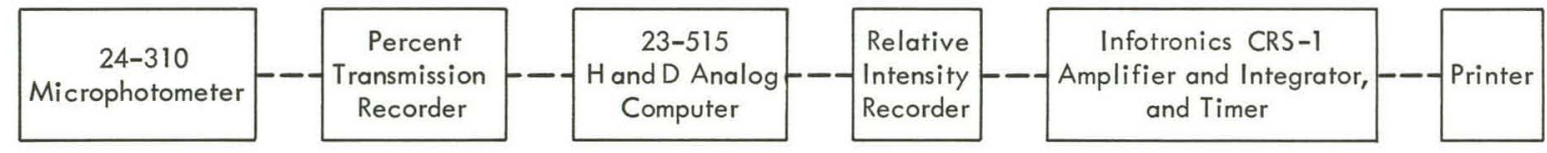

Figure 2. OUTLINE OF THE MICROPHOTOMETER SYSTEM.

spectrographic data are compared with chemical results obtained for the same series of steel samples using colorimetric methods.

When higher levels of boron were encountered in INOR-8 samples, a direct-reading emission spectrograph (1.5-meter grating instrument) was used to obtain comparison values. The results of this comparison are summarized in Table 3.

To ascertain the effects of inhomogenity on the analysis of steels and to determine if any type of analysis provided a biased answer, a series of Type 304 stainless steel samples were analyzed by four different laboratories. The results are summarized in Table 4. 
Table 1

SUMMARY OF BORON ANALYSES FOR VARIOUS MATERIAL TYPES

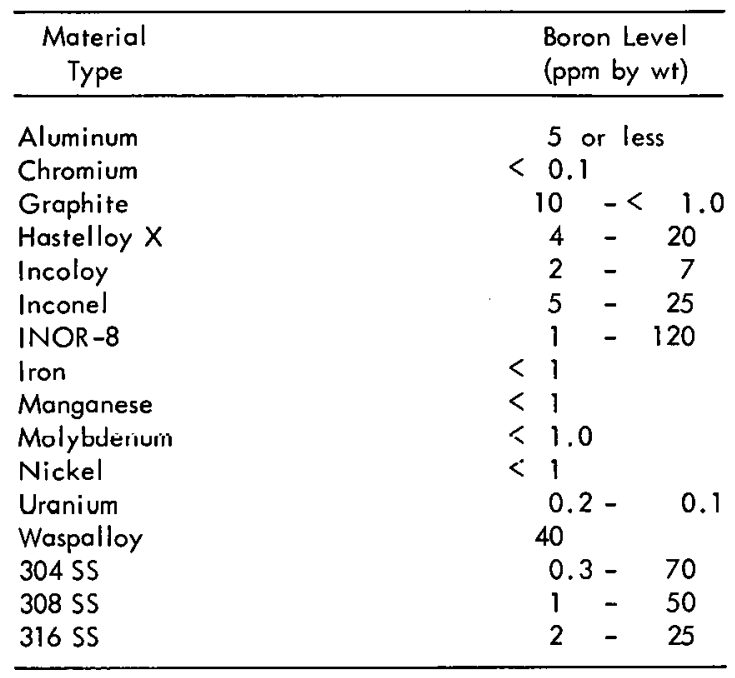

Table 2

COMPARISON OF SPARK-SOURCE MASS SPECTROGRAPHIC METHOD TO THE COLORIMETRIC METHOD

\begin{tabular}{ccc}
\hline & \multicolumn{3}{c}{ Analytical Method } \\
\cline { 2 - 3 } $\begin{array}{c}\text { Sample } \\
\text { Number }\end{array}$ & $\begin{array}{c}\text { Colorimetric } \\
\text { (ppm by wt) }\end{array}$ & $\begin{array}{c}\text { Spark Source } \\
\text { Mass Spectrograph } \\
\text { (ppm by wt) }\end{array}$ \\
\hline 1 & 4.1 & 2.6 \\
2 & 3.7 & 2.7 \\
3 & 5.0 & 2.3 \\
4 & 5.2 & 7.0 \\
5 & 4.4 & 4.2 \\
6 & 1.9 & 1.8 \\
7 & 2.5 & 2.5 \\
8 & 2.5 & 2.5 \\
9 & 7.0 & 4.2 \\
\hline
\end{tabular}

Table 3

COMPARISON OF THE SPARK SOURCE MASS SPECTROGRAPHIC METHOD TO THE DIRECT-EMISSION SPECTROGRAPHIC METHOD

\begin{tabular}{ccc}
\hline & \multicolumn{2}{c}{ Analytical Method } \\
\cline { 2 - 3 } $\begin{array}{c}\text { Sample } \\
\text { Number }\end{array}$ & $\begin{array}{c}\text { Spark Source } \\
\text { Mass Spectrograph } \\
\text { (ppm by wt) }\end{array}$ & $\begin{array}{c}\text { Quantometer } \\
\text { (ppm by wt) }\end{array}$ \\
\hline 1 & 20 & 10 \\
2 & 20 & 10 \\
3 & 6 & 7 \\
4 & 100 & 120 \\
5 & 120 & 80 \\
\hline
\end{tabular}


Table 4

SUMMARY OF BORON ANALYSIS FROM STAINLESS STEEL

\begin{tabular}{lcccc}
\hline & \multicolumn{4}{c}{ Boron Concentration per Type (1) } \\
\cline { 2 - 5 } Sample Location by wt) & Spark Source & $\begin{array}{c}\text { Spark Source } \\
\text { Spec 2(2) }\end{array}$ & $\begin{array}{c}\text { Wet } \\
\text { Chemistry }\end{array}$ \\
\hline 1 (top) & $1.3,1.3$ & 1.0 & $1.0,1.6$ & $3.1,4.0$ \\
2 & $0.8,1.4$ & 1.0 & $1.4,2.0$ & $0.2,2.6$ \\
3 (bottom) & - & - & $1.2,1.4$ & - \\
\hline
\end{tabular}

(1) These comparison data were provided by W. R. Martin of the Oak Ridge National Laboratory.

(2) $Y-12$ Laboratory.

To provide an indication of the precision and accuracy of the method, a series of three National Bureau of Standards samples were analyzed for their boron content. These standards were treated just as unknowns and the data obtained by visual estimation. The results, presented in Table 5, were accumulated over a period of several months.

Table.5

SPARK-SOURCE. MASS SPECTROGRAPHIC ANALYSES OF NBS STANDARD. SAMPLES FOR: BORON CONTENT

\begin{tabular}{ccc}
\hline Sample Number & $\begin{array}{c}\text { NBS Value } \\
\text { (ppm by wt) }\end{array}$ & $\begin{array}{c}\text { Spark Source } \\
\text { Mass Spectrograph } \\
\text { (ppm by wt) }\end{array}$ \\
\hline NBS 442 & 5 & $\begin{array}{l}5.5 \pm 1.8 \\
10 \pm 5 \\
\text { NBS } 443\end{array}$ \\
NBS 444 & 12 & $30 \pm 15$ \\
\hline
\end{tabular}

The data just presented were obtained by visual estimation alone and, as such, lack precision better than about $\pm 50 \%$ of the value. As better precision is desirable, a series of standard samples have been analyzed and measured with the microphotometer system.

Preliminary curves and emulsion calibration curves were obtained from the ratios of $\mathrm{Sn}-117$ to $\mathrm{Sn-119}$. This particular calibration curve was placed in the Hand D computer and all plates discussed were analyzed with the same curve in the instrument.

National Bureau of Standard Sample 443 was taken as a standard and measured for nine elements. From the observed concentration of these elements, a sensitivity factor was calculated, as shown in Table 6.

Next, NBS Samples 442 and 444 were read for the same nine elements using the same calibration curve. The raw data were then corrected for the sensitivity factors calculated in Table 6. 
Table 6

SENSITIVITY FACTORS DETERMINED IN STEELS

\begin{tabular}{lrcc}
\hline Element & Found $(1)$ & NBS Value $(1)$ & Sensitivity Factor $(2)$ \\
\hline $\mathrm{B}$ & 0.0071 & 0.0061 & 0.859 \\
$\mathrm{Co}$ & 0.0790 & 0.1120 & 1.416 \\
$\mathrm{Cr}$ & 20.6000 & 19.6900 & $0.956(2)$ \\
$\mathrm{Cu}$ & 0.1200 & 0.1200 & 1.000 \\
$\mathrm{Mn}$ & 2.4800 & 3.4000 & 1.371 \\
$\mathrm{Mo}$ & 0.0500 & 0.0660 & 1.320 \\
$\mathrm{Nb}$ & 0.0260 & 0.0290 & 1.116 \\
$\mathrm{Ni}$ & 5.2300 & 8.8600 & 1.520 \\
$\mathrm{Ti}$ & 0.0078 & 0.0034 & 0.436 \\
$\mathrm{~V}$ & & & $0.707(3)$ \\
\hline
\end{tabular}

(1) Values are atom percent. NBS values were calculated from certificates.

(2) Except for chromium, all sensitivity factors were determined using the copper concentration as the standard. Chromium sensitivity was determined using the iron concentration as a standard.

(3) Used previous sensitivity factor.

The precision data in Table 7 are calculated from no fewer than four datapoints and no more than ten data points. The error calculated assumes there is no error in the NBS values.

Table 7

PRECISION DATA FROM THE SPARK-SOURCE MASS SPECTROGRAPHIC ANALYSES OF NBS STANDARD ŚTEEELS

\begin{tabular}{|c|c|c|c|c|c|c|c|c|}
\hline \multirow[b]{2}{*}{ Element } & \multicolumn{2}{|c|}{ Found (1) } & \multicolumn{2}{|c|}{$\begin{array}{c}\text { Percent Relalive } \\
\text { Standard Deviation(2) }\end{array}$} & \multicolumn{2}{|c|}{ NBS Value(1) } & \multicolumn{2}{|c|}{$\begin{array}{l}\text { Percent Deviation } \\
\text { from NBS Value }\end{array}$} \\
\hline & NBS 442 & NBS 444 & NBS 442 & NBS 444 & NBS 442 & NBS $\overline{444}$ & NBS 442 & NBS $44 A$ \\
\hline B & 0.0028 & 0.184 & 32.0 & 43.1 & 0.0025 & 0.0167 & +12.0 & +10.2 \\
\hline Co & 0.109 & 0.186 & 16.0 & 6.1 & 0.122 & 0.2 & -10.8 & -7.0 \\
\hline $\mathrm{Cr}$ & 18.76 & 19.31 & 5.6 & 9.8 & 17.2 & 21.71 & -9.2 & -11.0 \\
\hline $\mathrm{Mn}_{n}$ & 2.49 & 3.84 & 5.8 & 27.2 & 2.89 & 4.45 & -13.8 & -13.7 \\
\hline Mo & 0.077 & 0.137 & 22.5 & 32.2 & 0.069 & 0.13 & +11.0 & +5.2 \\
\hline $\mathrm{Nb}$ & 0.023 & 0.113 & 24.4 & 17.2 & 0.019 & 0.118 & +20.0 & -4.1 \\
\hline $\mathrm{Ni}$ & 8.370 & 9.43 & 1.03 & 20.1 & 9.3 & 9.47 & -10.0 & -0.4 \\
\hline $\mathrm{Ti}$ & 0.0026 & 0.0182 & 48.5 & 9.5 & 0.0022 & 0.021 & +18.2 & -13.3 \\
\hline$V$ & 0.048 & 0.118 & 8.4 & 6.8 & 0.034 & 0.13 & +43.5 & -9.2 \\
\hline
\end{tabular}

(1) In atom percent,

(2) Relative Standard Deviation $=\frac{\sqrt{\frac{\left[E X^{2}\right] n-[E X]^{2}}{n(n-1)}}}{\text { Mean }} \times 100$.

The average relative standard deviation for NBS Sample 442 was $16.5 \%$; for Sample 444 it was $19.1 \%$. 
To observe more elements at different concentration levels, the same technique was applied to NBS Samples 461 and 462. This plate was interpreted with the same curves as for the previous NBS samples. The data are summarized in Table 8.

Table 8

SPARK-SOURCE MASS SPECTROGRAPHIC ANALYSWS

OF AN NBS MILD STEEL

(NBS Sample 462)

\begin{tabular}{llccc}
\hline Element & Found (1) & $\begin{array}{c}\text { Percent Relative } \\
\text { Standard Deviation }\end{array}$ & NBS Value (1) & $\begin{array}{c}\text { Percent Deviation } \\
\text { from NBS Value }\end{array}$ \\
\hline $\mathrm{Ag}$ & $<0.0003$ & & $<0.0002$ &. \\
$\mathrm{As}$ & 0.046 & 23.0 & 0.034 & +35.3 \\
$\mathrm{Bi}$ & 0.0014 & 28.6 & 0.025 & -44.0 \\
$\mathrm{Co}$ & 0.122 & .8 .2 & 0.102 & +19.6 \\
$\mathrm{Cr}$ & 0.87 & 3.1 & 0.78 & +11.0 \\
$\mathrm{Mn}$ & 0.88 & 2.4 & 0.94 & -6.4 \\
$\mathrm{Mo}$ & 0.04 & 11.2 & 0.046 & -13.0 \\
$\mathrm{Nb}$ & 0.066 & 10.1 & 0.057 & +15.8 \\
$\mathrm{Ni}$ & 0.73 & 12.5 & 0.658 & +12.3 \\
$\mathrm{~Pb}$ & 0.0020 & 50.0 & 0.0015 & +33.3 \\
$\mathrm{Sn}$ & 0.030 & 42.9 & 0.03 & +1.3 \\
$\mathrm{Ti}$ & 0.059. & 19.8. & 0.042 & +40.0 \\
$\mathrm{U}$ & 0.032. & 32.8. & 0.035 & -15.1 \\
$\mathrm{~V}$ & 0.082 & 10.6 & 0.063 & +30.0 \\
$\mathrm{~W}$ & 0.0086 & 19.8 & 0.016 & -46.2 \\
\hline
\end{tabular}

(1) In atom percent. 


\section{CONCLUSIONS}

Spark-source mass spectrometry provides a capability for measuring impurities in steels and nickel alloys to concentrations less than one part per million. In addition, the technique provides quantitative data over a concentration range of 20 to $0.0005 \%$ when standard samples are available. 


\section{Notes:}

1. Points represent the values obtained by the $Y-12$ Plant.

2. The bars represent the range of values obtained by other laboratories.

PPM

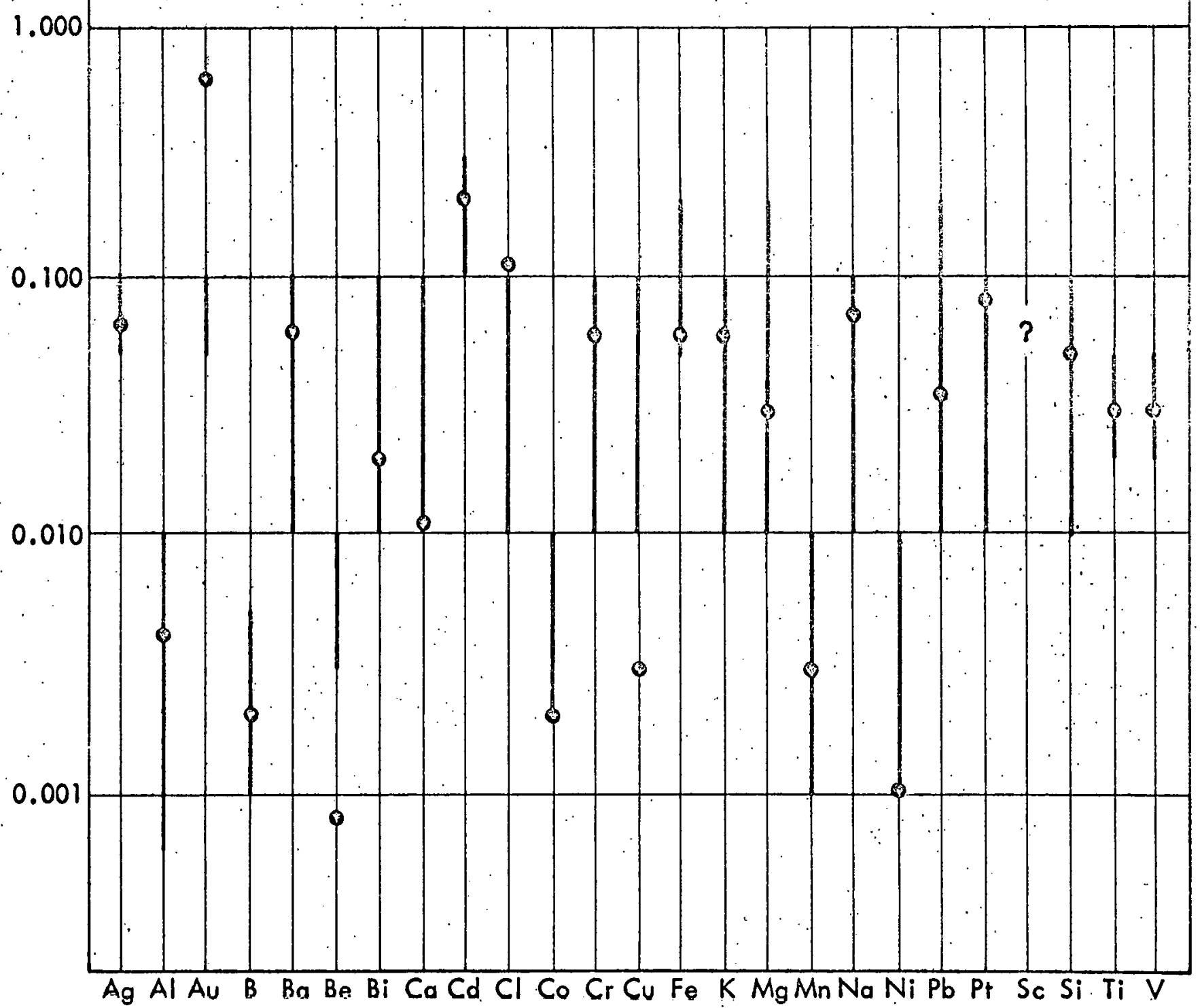

Attachment 1. COMPARISON OF. VALUES OBTAINED FROM AN ANALYSIS OF A NBSSUPPLIED, HIGH-PURITY ZINC SAMPLE.

$(Y-1543)$ 
Attachment II

COMPARISON OF DATA OBTAINED FROM SPARK SOURCE MASS SPECTROGRAPHIC ANALYSIS OF A HIGH-PURITY BERYLLIUM SAMPLE

(All Values in ppm)

\begin{tabular}{|c|c|c|c|c|c|}
\hline Element & $Y-12$ & ORNL & Element & $Y-12$ & ORNL \\
\hline $\mathrm{Ag}$ & $<0.01$ & $<0.02$ & $N$ & 1 & 1 \\
\hline $\mathrm{Al}$ & $<0.05$ & 0.10 & $\mathrm{Na}$ & 0.02 & 0.03 \\
\hline As & $<0.005$ & $<0.01$ & $\mathrm{Nb}$ & $<0.005$ & $<0.01$ \\
\hline Au & $<0.005$ & $<0.01$ & Nd & $<0.04$ & $<0.04$ \\
\hline$B$ & $<0.006$ & $<0.01$ & $\mathrm{Ni}$ & $<0.007$ & $<0.02$ \\
\hline $\mathrm{Ba}$ & $<0.005$ & $<0.01$ & 0 & 100 & 30 \\
\hline $\mathrm{Be}_{\boldsymbol{\theta}}$ & $M$ & $M$ & Os & $<0.02$ & $<0.02$ \\
\hline$B i$ & $<0.005$ & $<0.01$ & $\mathbf{p}$ & $<0.02$ & $<0.01$ \\
\hline $\mathrm{Br}$ & 0.1 & $<0.02$ & $\mathrm{~Pb}$ & $<0.01$ & $<0.02$ \\
\hline$C$ & 35 & 30 & Pd & $<0.03$ & $<0.04$ \\
\hline $\mathrm{Ca}$ & 0.005 & $<0.01$ & $\operatorname{Pr}$ & $<0.01$ & $<0.01$ \\
\hline $\mathrm{Cd}$ & 0.11 & $<0.03$ & $\mathrm{Pt}$ & $<0.02$ & $<0.03$ \\
\hline $\mathrm{Ce}_{\mathrm{e}}$ & $<0.01$ & $<0.01$ & Pu & $<0.01$ & \\
\hline $\mathrm{Cl}$. & 20 & 0.10 & $\mathrm{Rb}$ & $<0.005$ & $<0.01$ \\
\hline Co & $<0.015$ & $<0.01$ & $\operatorname{Re}$ & $<0.01$ & $<0.02$ \\
\hline $\mathrm{Cr}_{r}$. & $0.007-0.02$ & $<0.01$ & $\mathrm{Rh}$ & $<0.005$ & $<0.01$ \\
\hline Cs & $<0.005$ & $<0.01$ & Ru & $<0.02$ & $<0.03$ \\
\hline $\mathrm{Cy}$ & 0.07 & 0.01 & $\mathrm{~s}$ & $<0.10$ & $<0.10$ \\
\hline Dy & $<0.01$ & $<0.04$ & $S b$ & $<0.01$ & $<0.02$ \\
\hline Er & $<0.02$ & $<0.03$ & Sc & $<0.015$ & $<0.10$ \\
\hline Eu & $<0.01$ & $<0.02$ & Se & $<0.01$. & $<0.02$ \\
\hline$F$ & $<0.50$ & 3 & Si & $<0.15$ & $<1$ \\
\hline $\mathrm{Fe}$ & 0.04 & 0.01 & $\mathrm{~S}_{\mathrm{m}}$ & $<0.04$ & $<0.04$ \\
\hline Ga & $<0.03$ & $<0.02$ & Sn & $<0.02$ & $<0.03$ \\
\hline Gd. & $<0.01$ & $<0.04$ & $\mathrm{Sr}$ & $<0.01$ & $<0.01$ \\
\hline Ge & $<0.02$ & $<0.03$ & To & $<1$ & $<0.01$ \\
\hline $\mathrm{Hf}$ & $<0.01$ & $<0.03$ & $T b$ & $<0.01$ & $<0.01$ \\
\hline $\mathrm{Hg}$ & $<0.01$ & $<0.03$ & $\mathrm{Te}$ & $<0.01$. & $<0.03$ \\
\hline Ho & $<0.01$ & $<0.01$ & Th & $<0.02$ & $<0.01$ \\
\hline 1 & $<0.01$ & $<0.01$ & $\mathrm{Ti}$ & 0.015 & $<0.01$ \\
\hline $\ln$ & 0.015 & $<0.01$ & $T I$ & $<0.01$ & $<0.01$ \\
\hline Ir & $<0.01$ & $<0.02$ & $T m$ & $<0.01$ & $<0.01$ \\
\hline$K$ & $0.015-0.05$ & $<0.01$ & $U$ & $<0.015$ & 0.03 \\
\hline La & $<0.01$ & $<0.01$ & V & 0.005 & $<0.01$ \\
\hline $\mathrm{Li}$ & 0.05 & $<0.10$ & W: & $<0.01$ & $<0.03$ \\
\hline Lu & $<0.01$ & $<0.01$ & $Y$ & $<0.005$ & $<0.01$ \\
\hline $\mathrm{Mg}$ & $<0.03$ & $<0.01$ & $Y b$ & $<0.01$ & $<0.03$ \\
\hline$M_{n}$ & $0,05-0,15$ & 0.10 & $\mathrm{Zn}$ & $0.02-0.07$ & $<0.02$ \\
\hline Mo & $<0.02$ & $<0.04$ & $\mathrm{Zr}$ & $<0.02$ & $<0.06$ \\
\hline
\end{tabular}

